\title{
Host-Intestinal Microflora Interactions: Role of the Mucus and Gynolactose
}

\author{
Marie Bénédicte Romond, ${ }^{1}$ Nour-eddine Chadli, ${ }^{1}$ Tomotari Mitsuoka ${ }^{2}$ \\ and Charles Romond ${ }^{1}$ \\ 1INSERM 146, 369 rue Jules Guesde, Villeneuve d'Ascq, France and \\ ${ }^{2}$ Laboratory for Intestinal Flora, FRP, RIKEN, Wako, Saitama 351-01
}

(Received for publication, August 20, 1990)

\begin{abstract}
Mucus and gynolactose might control host-Bifidobacterium interactions. Their respective roles were investigated in this study using gnotobiotic mice. By comparing glycoprotein SDS-PAGE profiles, mucus from various murine lines $\left(\mathrm{NC}, \mathrm{CF}_{1}, \mathrm{BALB} / \mathrm{c}\right.$ and $\mathrm{C}_{3} \mathrm{H}$ ) were differentiated. We attempted then to determine the intestinal substrates utilized by various bifidobacteria. First, NC and $C_{1}$ germfree mice received an inoculum of a murine species, $B$. animalis. Bacteria utilized the glycosyl fraction of several $\mathrm{CF}_{1}$ glycocompounds. No such extensive degradation was observed in $\mathrm{NC}$ mice. In constrast, both $\mathrm{NC}$ and $\mathrm{CF}_{1}$ mice responded to colonization by modifying hexosamine composition of their high molecular weight mucins. Three human species (B. bifidum, B. breve and B. longum) were then assayed for their in vivo capacity to degrade murine mucus from $\mathrm{C}_{3} \mathrm{H}$ mice. $B$. bifidum utilized extensively glycoproteins from the mucus, whereas $B$. longum and $B$. breve were unable to degrade them. However, none of the human strains led to intestinal mucins modification. Origin of the strains seemed to be a factor controlling the host response. Finally, gynolactose effect was investigated in germfree, $B$. breve-associated, and infant flora-associated $\mathrm{C}_{3} \mathrm{H}$ mice. Few modifications to mucus composition were noticed in the first two cases. In infant flora-associated mice, new intestinal glycoproteins and proteins were detected but bacterial counts were not changed. Host response to gynolactose might depend on the implantation of some unknown intestinal bacteria. It is likely that the proliferation of bifidobacteria shown in breast-fed infants does not correspond to a direct gynolactose promoting effect. But it is probably related to mucus modification induced by gynolactose.
\end{abstract}

Key words: gynolactose; mucus; Bifidobacterium; intestinal microflora; gnotobiotic mice

Dialyzable sugars isolated from human milk were historically divided into two groups, allolactose and gynolactose (22). The first one corresponds to well-known 
lactose and is secreted in high concentration (around $70 \mathrm{~g} /$ liter) during the first months of lactation. The second one (about $10 \mathrm{~g} /$ liter) is constituted of various oligosaccharides whose molecular weights do not exceed $10 \mathrm{kDa}(10,18,28)$. More than 50 different structures are now described $(7,18)$. Common constitutive sugars are D-glucose (D-GlC), D-galactose (D-Gal) and L-fucose (L-Fuc). But no mannose (Man) or $N$-acetylgalactosamine (NAcGal) are found. A few oligosaccharides such as 2 '-fucosidolactose, 3-fucosidolactose, lactodifucotetraose, 2'-fucosido-3'-galactosidolactose, 3'-lactaminyl lactose and 6'-lactaminyl lactose, do not contain $\mathrm{N}$-acetylglucosamine (NAcGlc). But the majority, called nitrogen-containing oligosaccharides, do contain NAcGlc in their structure. They are usually derived from lacto- $N$-tetraose or lacto- $N$-neotetraose (Table 1). Sialic acids (NANA) content subdivided nitrogen-containing oligosaccharides into neutral and acidic oligosaccharides (17).

In fact, extensive documentation on gynolactose biochemical composition and oligosaccharides structure contrasts with the lack of information on their biological properties. Considering the concentration of each gynolactose oligosaccharide isolated, it seems unlikely that they could be a source of nutrient for the infant. Some observations indicated, on the other hand, that they might participate in the protection of infant health against pathogens. Diarrhea occurred rarely in breastfed infants compared to bottle-fed ones (9). Since infant formulas or cow's milk did not contain gynolactose (23), one might assume that human milk oligosaccharides could play a role in the prevention of the infectious process. For instance, fucosecontaining oligosaccharides inhibited Vibrio cholerae adhesion to red cells $(12,13)$. In contrast, no inhibition of Escherichia coli adhesion to human colonocytes was shown (21). However, breast-fed infants harbored lower $E$. coli counts than bottle-fed ones $(4,20)$. As a concomitant higher bifidobacterial count is usually observed in the breast-fed population, repression of $E$. coli by bifidobacteria was suggested (4, 20). Such a hypothesis was supported by works using gnotobiotic models and showing a slight repression of $E$. coli by bifidobacteria (8). And the relative overproliferation of bifidobacteria observed in breast-fed infants was thought to be related to presence of growth-promoting oligosaccharides in human milk. Most of the neutral $N$-acetylglucosamine-containing oligosaccharides actually promote in vitro the growth of B. bifidum (11). Thus, it was tempting to explain the intestinal bifidobacterial over-growth by an in situ utilization of growth-promoting oligosaccharides. But, two arguments oppose this view. First, in the gut of breast-fed infants, who were either premature (27) or suffering from a vitamin $\mathrm{K}$ deficiency (1), colonization (when it occurred) was poor and slow, suggesting that some hostsecreted substrates playing a role in implantation and maintenance of bifidobacteria were missing. Second, B. bifidum is the single bifidobacterial species requiring human milk oligosaccharides but other bifidobacterial species are commonly recovered from breast-fed infant stools (20). Thus, relationships between gynolactose host and microflora appeared to be more complex than expected.

For ethical and technical reasons, such complex interactions cannot be studied in human populations. Therefore we used gnotobiotic mice to investigate the 
Table 1. A few structures of nitrogen-containing oligosaccharides isolated from gynolactose $(10,17,18)$

\begin{tabular}{|c|c|}
\hline Name & Structure \\
\hline Lacto- $N$-tetraose & Gal $\beta 1-3 N A c G l c \beta 1-3 G a l \beta 1-4 \mathrm{Glc}$ \\
\hline Lacto- $N$-neotetraose & Gal $\beta 1-4$ NAcGlc $\beta 1-3 \mathrm{Gal} \beta 1-4 \mathrm{Glc}$ \\
\hline Lacto- $N$-hexaose & $\begin{array}{c}\text { Gal } \beta 1-3 N A c G l c \beta 1-3 \mathrm{Gal} \beta 1-4 \mathrm{Glc} \\
\beta \\
1 \\
\mid \\
6 \\
\text { Gal } \beta 1-4 N A c G l c\end{array}$ \\
\hline Lacto- $N$-neohexaose & $\begin{array}{c}\text { Gal } \beta 1-4 \mathrm{NAcGlc} \beta 1-3 \mathrm{Gal} \beta 1-4 \mathrm{Glc} \\
\beta \\
1 \\
1 \\
6 \\
\text { Gal } \beta 1-4 \mathrm{NAcGlc}\end{array}$ \\
\hline Lacto- $N$-fucopentaose II & $\begin{array}{c}\mathrm{Gal} \beta 1-3 \mathrm{NAcGlc} \beta 1-3 \mathrm{Gal} \beta 1-4 \mathrm{Glc} \\
\alpha \\
1 \\
\mid \\
4 \\
\text { Fuc }\end{array}$ \\
\hline Lacto- $N$-fucopentaose III & $\begin{array}{c}\mathrm{Gal} \beta 1-4 \mathrm{NAcGlc} \beta 1-3 \mathrm{Gal} \beta 1-4 \mathrm{Glc} \\
\alpha \\
1 \\
\mid \\
4 \\
\text { Fuc }\end{array}$ \\
\hline Pentaose A & $\begin{array}{l}\mathrm{Gal} \beta 1-3 \mathrm{NAcGlc} \beta 1-3 \mathrm{Gal} \beta 1-4 \mathrm{Glc} \\
\alpha \\
2 \\
1 \\
3 \\
\text { NANA }\end{array}$ \\
\hline Pentaose C & $\begin{array}{l}\mathrm{Gal} \beta 1-4 \mathrm{NAcGlc} \beta 1-3 \mathrm{Gal} \beta 1-4 \mathrm{Glc} \\
\alpha \\
2 \\
\mid \\
6 \\
\text { NANA }\end{array}$ \\
\hline
\end{tabular}


respective role of each actor. We first attempted to characterize in mucus the substrates for various bifidobacteria. Two strains of mice inoculated with a murine bifidobacterial species were used in a first model to determine the adaptive capacity of bifidobacteria to different mucus. In a second step, a single murine strain was inoculated with three human Bifidobacterium. Finally, we analyzed host response to gynolactose administration, according to the microbial status of the mice (germfree, $B$. breve-associated and infant flora-associated mice).

\section{MATERIALS AND METHODS}

Animals. Male $\mathrm{CF}_{1}$ and $\mathrm{NC}$ mice (2 months old) were raised under germfree conditions at the Institute of Physical and Chemical Research (Riken, Tokyo, Japan). Germfree male $\mathrm{C}_{3} \mathrm{H}$ mice were provided by the Centre d'Elevage d'Animaux de Laboratoire (CEAL, Orléans, France).

CMF pellets (Oriental Yeast Co. Ltd, Tokyo, Japan) sterilized by $\gamma$-radiation ( $5 \mathrm{Mrad}$ ) were given to $\mathrm{CF}_{1}$ and $\mathrm{NC}$ mice. $\mathrm{C}_{3} \mathrm{H}$ mice received $\mathrm{RO}_{3}$ pellets (UAREpinay/Orge, France) sterilized by $\gamma$-radiation $(25 \mathrm{Mrad})$. Water autoclaved for $2 \mathrm{hr}$ at $121^{\circ} \mathrm{C}$ was given ad libitum to all mice.

Germfree and ex-germfree mice were kept in isolators sterilized by a $2 \%$ peracetic acid solution.

Bacteria. $B$. animalis $\mathrm{IR}_{1}$ was originally isolated from conventional mice at Riken Institute and identified using DNA-DNA hybridization (16). $\mathrm{CF}_{1}$ and NC germfree mice were inoculated with brain heart infusion (BHI) broth (Difco Laboratories, Detroit, U.S.A.) cultures grown for $24 \mathrm{hr}$ at $37^{\circ} \mathrm{C}$.

$B$. bifidum $\mathrm{AA}_{22}, B$. longum $\mathrm{F}_{1}$ and $B$. breve $\mathrm{BF}_{1}$ were originally isolated from infants at the Faculty of Pharmacy (Lille II, France). Identification was performed using Mitsuoka method (20) and DNA-DNA hybridization. $\mathrm{C}_{3} \mathrm{H}$ germfree mice were inoculated with $\mathrm{BHI}$ cultures grown for $24 \mathrm{hr}$ at $37^{\circ} \mathrm{C}$.

The various strains used in this study were maintained frozen at $-80^{\circ} \mathrm{C}$ in BHI broth.

Infant fecal microflora. Feces (around $20 \mathrm{mg}$ ) from a 10-day-old bottle-fed infant were collected by using a sterile "culturette" Swab (Marion Scientific, U.S.A.) in order to maintain an anaerobic atmosphere during the transport. The swab was disrupted by shaking in $10 \mathrm{ml}$ of a Ringer modified solution (24). The mice were orally inoculated with $0.5 \mathrm{ml}$ of the bacterial suspension.

Experimental gut colonization. Confirmation of bifidobacterial gut colonization was determined 2 or 3 days post-inoculation and at specific intervals by fecal viable counts using Ringer modified diluent $(24,25)$. Fresh feces were collected from each mouse and appropriate dilutions plated onto brain-heart medium supplemented with agar $\left(10 \mathrm{~g} /\right.$ liter). Plate dilutions were incubated for 3 days at $41^{\circ} \mathrm{C}$ in an anaerobic chamber. In ex-germfree mice inoculated with an infant flora, total aerobic and anaerobic fecal bacterial counts were determined 15 days postinoculation and at specific intervals during gynolactose administration. Bifidobacteria and spore-forming rods were quantified at the same time (2). 
Gynolactose administration. Dialyzable human milk oligosaccharides (gynolactose) were kindly given by Dr. Strecker (Biochemistry Laboratory, Lille I, France). A $1 \%(\mathrm{w} / \mathrm{v})$ sterile solution was administered ad libitum for 7 days to germfree and ex-germfree mice.

Analysis of mucous constituents. At specific intervals, fresh feces were collected from each of the germfree and ex-germfree mice, they were pooled and analyzed for mucous constituents. Mucous constituents were extracted by water (25). Lyophilized crude extracts were fractionated on Sephacryl S200 column (K 15; Pharmacia, Sweden) or Superose 6 FPLC column (H 16/50; Pharmacia). Elution was performed with a 0.1 м Tris- $\mathrm{HCl}$ buffer $(\mathrm{pH} 8.0)$ containing $0.02 \%$ sodium azide and $0.2 \mathrm{~m} \mathrm{NaCl}$.

Electrophoresis. Whole extract components were identified by SDS-PAGE. Proteins were detected by Coomassie Blue or by silver staining procedures. Periodic acid-Schiff (PAS) reaction was used for glycocompounds (19).

Hexosamine determination. Analysis for hexosamines constituents was performed using the method of Morgan-Elsson after a hydrolysis of the hexosaminyl linkages with $\mathrm{HCl}(4 \mathrm{M})$ at $100^{\circ} \mathrm{C}$ for $4 \mathrm{hr}(5)$.

\section{RESULTS}

\section{Comparison of Mucus Composition According to the Mouse Strain}

Fecal germfree crude extracts from $\mathrm{BALB} / \mathrm{c}, \mathrm{C}_{3} \mathrm{H}, \mathrm{NC}$ and $\mathrm{CF}_{1}$ mice were analyzed for their glycocompound composition by SDS-PAGE stained by PAS procedure. Several differences in glycosyl moieties were observed between the

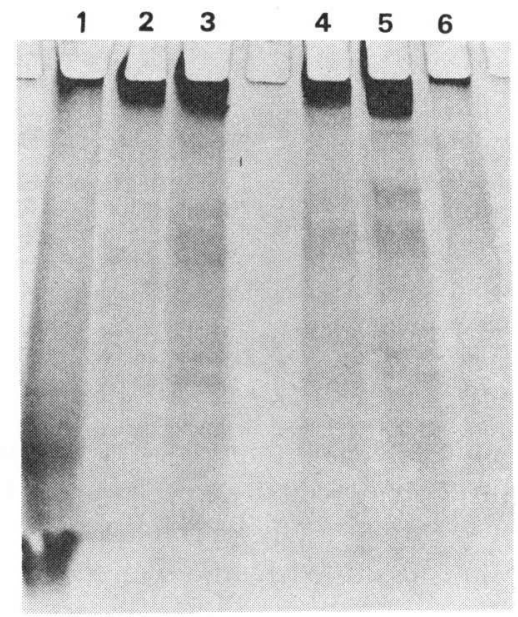

Fig. 1. PAS-stained SDS-PAGE profiles of mucus from various mouse strains. Lane 1, water crude extract of FR1 food pellets; lane 2, fecal BALB/c crude extract; lane 3, fecal $\mathrm{C}_{3} \mathrm{H}$ crude extract; lane 4 , fecal $\mathrm{NC}$ crude extract; lane 5 , fecal $\mathrm{CF}_{1}$ crude extract; lane 6, water crude extract of CMF food pellets. 
a

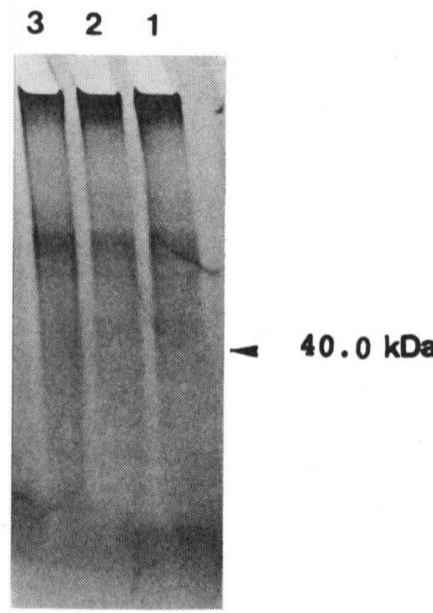

b

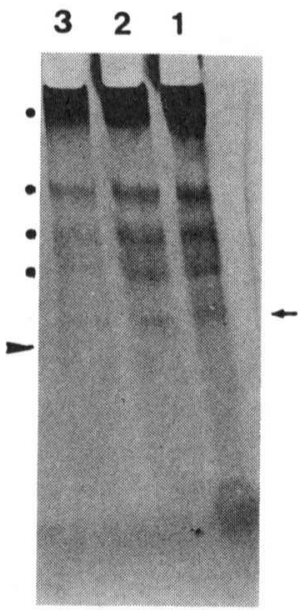

Fig. 2. Effect of $B$. animalis on $\mathrm{NC} \mathrm{(a)} \mathrm{and} \mathrm{CF}_{1}$ (b) mucus composition analyzed by PAS-stained SDS-PAGE. Lane 1, germfree fecal $\mathrm{NC}$ and $\mathrm{CF}_{1}$ crude extracts; lane 2, fecal $\mathrm{NC}$ and $\mathrm{CF}_{1}$ crude extracts 3 days post-inoculation; lane 3 , fecal $\mathrm{NC}$ and $\mathrm{CF}_{1}$ crude extracts 21 days post-inoculation. The arrow shows one glycoprotein utilized extensively by $B$. animalis. Circles correspond to partly degraded glycocompounds.

Table 2. Hexosamines concentration in fractionated mucous constituents from germfree (GF) and ex-germfree (EGF) $\mathrm{NC}$ and $\mathrm{CF}_{1}$ mice

\begin{tabular}{|c|c|c|c|c|}
\hline \multirow{2}{*}{$\begin{array}{l}\text { Fractions } \\
\text { M.W. (kDa) }\end{array}$} & \multicolumn{2}{|c|}{ GF } & \multicolumn{2}{|c|}{$\mathrm{EGF}^{a)}$} \\
\hline & $\mathrm{NC}$ & $\mathrm{CF}_{1}$ & $\mathrm{NC}$ & $\mathrm{CF}_{1}$ \\
\hline$>5,000$ & 42 & 36 & $112^{b)}$ & $169^{b)}$ \\
\hline $1,000-5,000$ & 31 & 17 & 26 & 13 \\
\hline $100-1,000$ & 34 & 31 & 31 & $10^{c)}$ \\
\hline $40-300$ & 58 & 33 & 29 & 8c) \\
\hline $30-45$ & 54 & 78 & 81 & $13^{c)}$ \\
\hline $30-40$ & 43 & 47 & 36 & 34 \\
\hline
\end{tabular}

a) Analysis was performed 3 weeks after $B$. animalis inoculation.

b) Increase of hexosamines content.

c) Decrease of hexosamines content.

murine lines (Fig. 1). Some glycocompounds were common to all mouse strains such as mucin-like glycoproteins detected at the top of the gel. But others were excreted by a single mouse strain. Glycoproteins seemed to be endogenous in origin as no such bands were identified in the water extract from the food pellets.

Experimental Gut Colonization of $N C$ and $C F_{1}$ Mice with a Murine Bifidobacterial Strain

$B$. animalis $\mathrm{IR}_{1}$ colonized the gut of each murine line within $24 \mathrm{hr}$. Colonization levels were similar in both groups 3 weeks post-inoculation $(9.1 \pm 0.6 \mathrm{cfu} / \mathrm{g}$ 


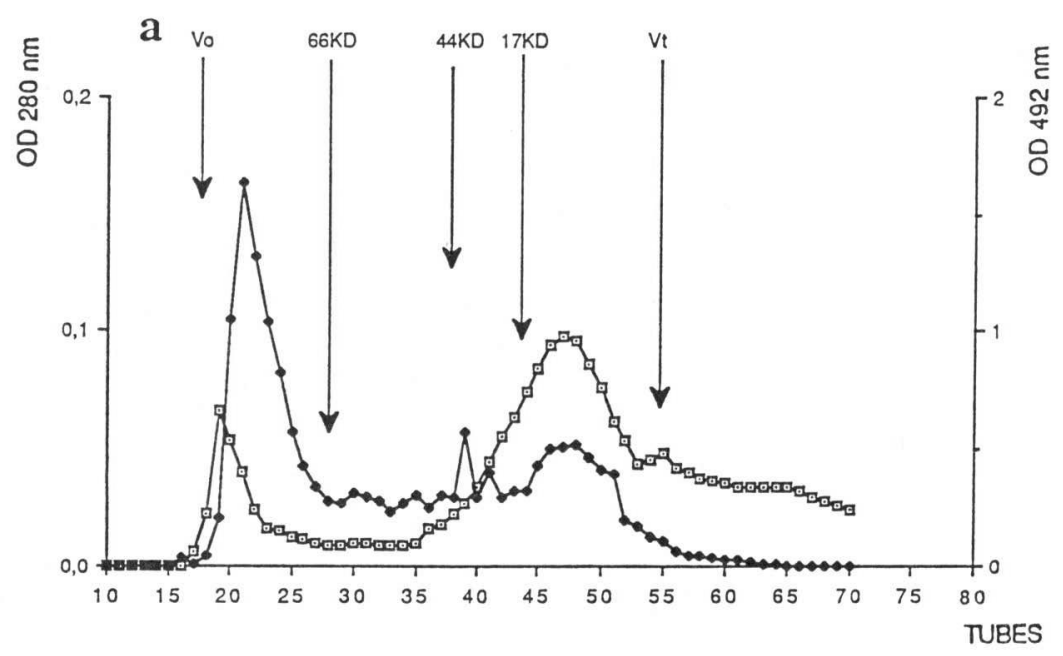

b

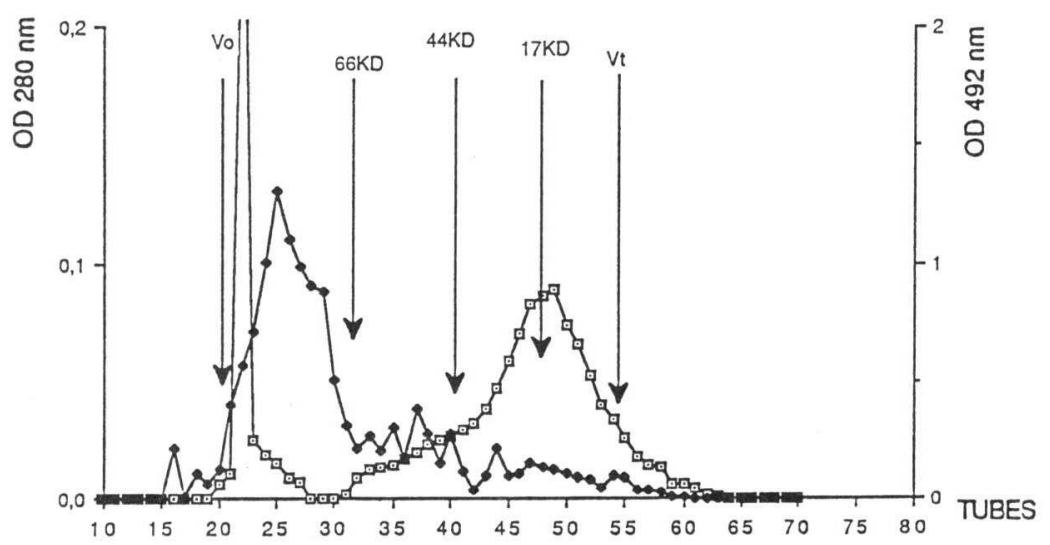

Fig. 3. Gynolactose effect on S200 chromatographic profiles from germfree mucus. $3 \mathrm{a}$ : control. $3 \mathrm{~b}$ : 7-day gynolactose administration. White squares correspond to $A_{280 \mathrm{~nm}}$ elution profiles and black ones to carbohydrates elution profiles determined according to Dubois method $(6)$.

in $\mathrm{NC}$ mice, $9.5 \pm 0.1$ in $\mathrm{CF}_{1}$ mice).

No obvious change in electrophoretic patterns of glycoproteins was noticed after bifidobacterial colonization of NC gut (Fig. 2a). On the contrary, one glycoprotein (around $40 \mathrm{kDa}$ ) secreted by $\mathrm{CF}_{1}$ mice disappeared within three weeks after inoculation with $B$. animalis (Fig. 2b). Three other glycoproteins and mucin-like glycoprotein were less stained, suggesting an incomplete utilization by $B$. animalis $\mathrm{IR}_{1}$.

$\mathrm{NC}$ and $\mathrm{CF}_{1}$ germfree and ex-germfree crude extracts were then applied to a Superose 6 FPLC column. Chromatographic elution profiles were similar in their 

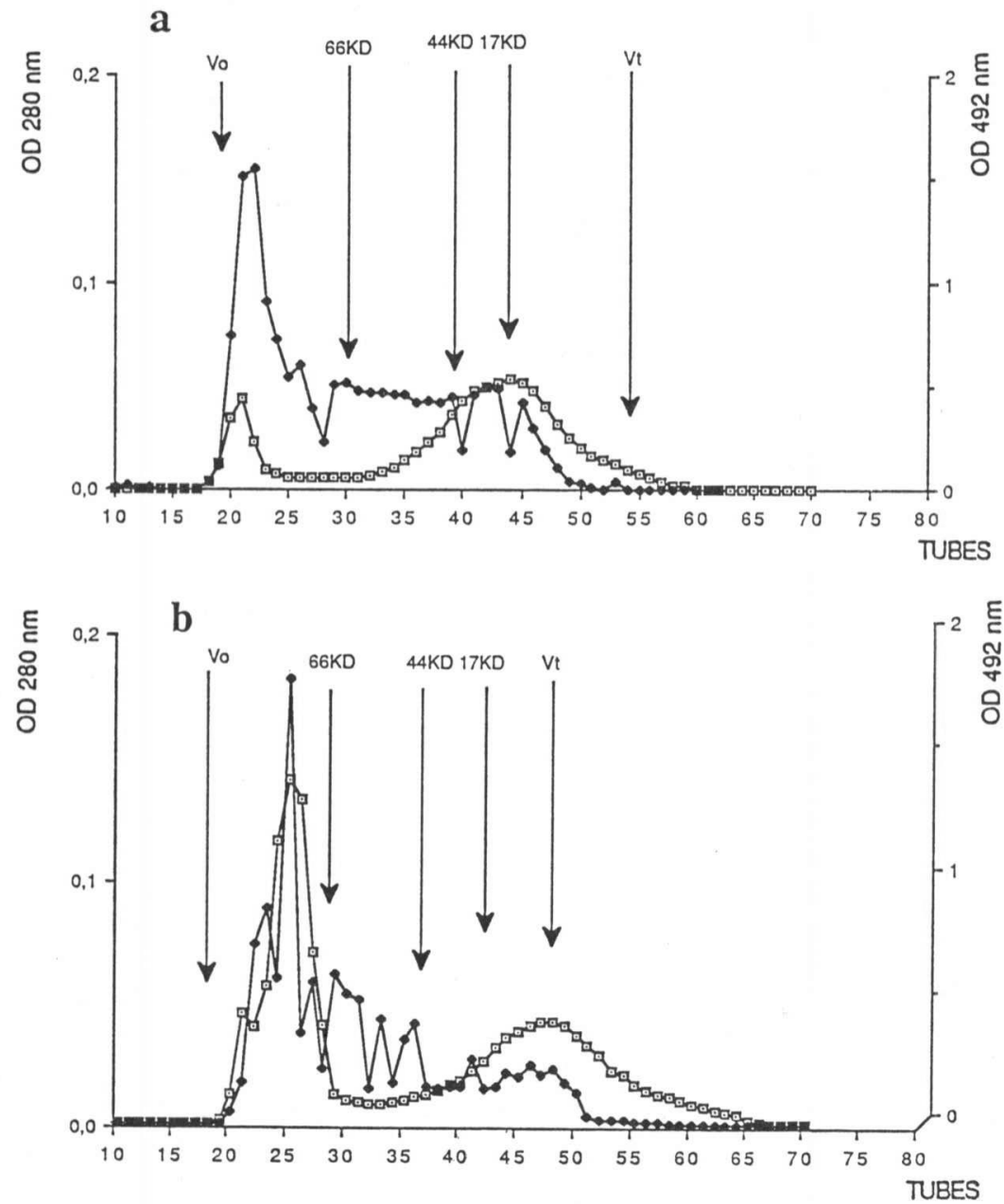

Fig. 4. Gynolactose effect on S200 chromatographic profiles from ex-germfree mucus. 4a: control. 4b: 7-day gynolactose administration. White squares correspond to $A_{280 \mathrm{~nm}}$ elution profiles and black ones to carbohydrates elution profiles determined according to Dubois method $(6)$.

absorbance at $280 \mathrm{~nm}$. Six different fractions were collected in each case and analyzed for their hexosamines content. Hexosamines concentration in $\mathrm{NC}$ and $\mathrm{CF}_{1}$ germfree fractions were almost identical (Table 2).

Surprisingly, $B$. animalis colonization led to an increase of the hexosamines concentration in $\mathrm{NC}$ and $\mathrm{CF}_{1}$ fraction 1 . Both fractions 1 contained exclusively mucin-like glycoproteins as demonstrated by SDS-PAGE (data not shown). NC glycocompounds of lower molecular weight did not show any modification to their hexosamines content. In contrast, a significant decrease was observed for $\mathrm{CF}_{1}$ glycocompounds ranging in molecular weight between 30 and 1,000 kDa (Table 2). 


\section{Experimental Gut Colonization of $C_{3} H$ Mice with Human Bifidobacterial Strains}

$B$. bifidum $\mathrm{AA}_{22}, B$. longum $\mathrm{F}_{1}$ and $B$. breve $\mathrm{BF}_{1}$ colonized the mouse gut within $24 \mathrm{hr}$. Bifidobacterial counts were similar to $B$. animalis ones. Two $\mathrm{C}_{3} \mathrm{H}$ glycoproteins were used extensively by $B$. bifidum, as demonstrated by SDS-PAGE (data not shown). In contrast, $B$. longum and $B$. breve did not degrade any $\mathrm{C}_{3} \mathrm{H}$ fecal glycocompounds.

\section{Gynolactose Effect on the Host and on the Bacterial Floras}

No modification to the bacterial counts was noticed under gynolactose either in $B$. breve-associated mice or in infant flora-associated mice.

A 7-day gynolactose administration to $\mathrm{C}_{3} \mathrm{H}$ germfree or $B$. breve-associated mice did not modify SDS-PAGE glycocompound profile. However, comparison of S200 chromatographic profiles during gynolactose intake showed extensive changes in protein and carbohydrates patterns after a 7-day gynolactose intake (Fig. 3a, b). No such modification was noticed 2 days following the first intake. Three days post-administration, gynolactose effect on S200 chromatographic profile was no longer observed (data not shown).

Experimental gut colonization with the human infant microflora led to the degradation of some proteins and a glycoprotein as demonstrated by SDS-PAGE (data not shown). Confirmation of protein utilization was shown on S200 chromatographic profile (Fig. 4a).

Gynolactose administration to ex-germfree mice led to an extensive modification to SDS-PAGE profiles and S200 chromatographic patterns (Fig. 4b). New glycoprotein bands (above $40 \mathrm{kDa}$ ) were detected on PAS-stained SDS-PAGE. Two new protein bands (around $20 \mathrm{kDa}$ ) were shown after a 4-day gynolactose intake. In addition, protein surface ratio of peak 1 on peak 2 was inversed compared to the control (Fig. $4 \mathrm{a}, \mathrm{b}$ ).

\section{DISCUSSION}

Each mouse strain excreted mucus characterized by its glycoprotein composition as shown on SDS-PAGE profiles (Fig. 1). B. animalis proliferation in NC and $\mathrm{CF}_{1}$ mice was almost identical, suggesting that the strain found its substrates for growth in both murine hosts. In vitro, B. animalis utilized mainly $\mathrm{N}$ acetylglucosamine-containing compounds (data not shown). However, no NC glycoprotein was degraded after $B$. animalis implantation (Fig. 2a) but protein concentration dramatically decreased in fractions containing glycoproteins ranging in molecular weight between 100 and $5,000 \mathrm{kDa}$ (data not shown). B. animalis probably utilized the protein core of NC high-molecular-weight glycoproteins. It contrasted with the glycosyl structures the bifidobacteria utilized in $\mathbf{C F}_{1}$ mucus (Fig. 2b, Table 2). Unability of B. animalis to utilize glycosyl components in NC mice could partly explain the poor bifidobacterial colonization observed in this murine line (14). For instance, administration of a clostridial flora led to the repression of $B$. animalis in NC monoassociated mice. No such effect was observed 
in $\mathrm{CF}_{1}$ mice (15). Clostridia proteases are well known for their capacity to digest a wide variety of proteins. $B$. animalis probably could not compete for the protein substrates it utilized in NC mice as it possesses few protease activities. On the contrary, the bifidobacteria were adapted to $\mathrm{CF}_{1}$ glycocompounds and could compete with clostridia with efficiency. However, the ability to utilize intestinal glycosyl components seemed in some cases insufficient. Human B. bifidum, a species which required $N$-acetylglucosamine-containing glycocompounds, degraded to a great extent $\mathrm{C}_{3} \mathrm{H}$ mucins and glycoproteins as demonstrated by SDS-PAGE (26). However, Boureau et al (3) showed that infection with Clostridium cocheleatum led to the reduction of the bifidobacterial population. They confirmed that $C$. cochleatum possessed the necessary enzymatic activities to degrade mucin oligosaccharides but it did not possess mucin proteins-degrading enzymes. C. cochleatum was unable to colonize germfree mice, but it did when $B$. bifidum was implanted. Having a wider variety of osidases and utilizing the same glycoproteins, $C$. cochleatum might reduce $B$. bifidum population by competition for common intestinal glycosyl substrates (3). Interestingly, human $B$. bifidum strain did not lead to an increase of mucin hexosamines content (data not shown). It seems that the host did not respond to human oligosaccharides-dependent bifidobacteria as it did after inoculation of murine ones. It raises the question of the ecological meaning of such a host response. We might assume that new mucin structures secreted by the host would favor oligosaccharidesdependent bifidobacteria and allow their maintenance at high level (which was the situation for $B$. animalis).

It is likely that $B$. longum and $B$. breve, whose growth did not depend on mucin oligosaccharides, are not influenced by such mechanisms. They did not utilize intestinal glycoproteins but easily colonized $\mathrm{C}_{3} \mathrm{H}$ germfree mice. Furthermore, $B$. breve colonization did not improve delay of host response to gynolactose administration. After a 7-day gynolactose intake, modifications to S200 chromatographic patterns occurred for both germfree and monoassociated mice, whereas similar changes were observed sooner in ex-germfree mice associated with the infant flora. In germfree and $B$. breve-monoassociated mice, increase of peak 1 to peak $2 A_{280}$ ratios was probably not related to a protein modification since Coomassie Bluestained SDS-PAGE profile was similar to the control one. It is likely that mucins release was increasing but PAS-stained SDS-PAGE did not allow us to confirm this hypothesis. In mixed flora-associated mice, the phenomena were more obvious as new glycoproteins and proteins were detected. Only four days of gynolactose administration led to an extensive change in mucous composition. The bacterial flora seemed to act as an activator of the host response to gynolactose intake. Predominant bacterial counts did not increase, suggesting that they are probably not involved in the process.

In conclusion, various factors influenced microbial equilibriums in vivo: quality of mucous constituents secreted by the host and ability of the bacterial strain itself to induce a host response. In this context, it appears that gynolactose does not act directly on the microbial flora but induces a host response amplified by the presence of intestinal bacteria. Modification to microbial flora might occur in a second 
step by utilizing the new substrates secreted. But further investigations are required to confirm this hypothesis.

Acknowledgments. We acknowledge Dr. T. Fujisawa for the identification of $B$. animalis $\mathrm{IR}_{1}$ by DNA homology. We also thank T. Oowada and A. Ozaki for their technical assistance in the management of the mice.

\section{REFERENCES}

(1) Benno, Y., K. Sawada, and T. Mitsuoka. 1985. The intestinal microflora of infants: fecal flora of infants with vitamin K deficiency. Microbiol. Immunol. 29: 243-250.

(2) Bezirtzoglou, E., M.B. Romond, and C. Romond. 1989. Modulation of Clostridium perfringens intestinal colonization in infants delivered by caesarean section. Infection 17: 232-236.

(3) Boureau, H., C. Guichet, M.B. Romond, and P. Bourlioux. 1990. Anaerobic strains responsible for the colonisation resistance to Clostridium difficile: importance of the first strain colonising the digestive tract of axenic mice, p. 107-112. In S.P. Borriello (ed.), Clinical and molecular aspects of anaerobes, Wrighston Biomedical Publishing Ltd., London.

(4) Bullen, C.L., P.V. Tearle, and M.G. Stewart. 1977. The effect of "humanized" milks and supplemented breast-feeding on the fecal flora of infants. J. Med. Microbiol. 10: 403-413.

(5) Chaplin, M.F. 1986. Monosaccharides, p. 1-8. In M.F. Chaplin and J.F. Kennedy (eds.), Carbohydrate analysis, a practical approach, IRL Press, Oxford.

(6) Dubois, M., K. Gilles, J.K. Hamilton, and F. Smith. 1956. Colorimetric method for determination of sugars and related substances. Anal. Chem. 28: 350-356.

(7) Egge, H., A. Dell, and H. von Nicolai. 1983. Fucose containing oligosaccharides from human milk. Arch. Biochem. Biophys. 224: 235-253.

(8) Faure, J.C., D. Schellenberg, A. Bexter, and H.P. Würzner. 1982. Barrier effect of B. longum on $E$. coli in the germfree rat. Int. Vitam. Nutr. Res. 52: 225.

(9) Feachem, R.G., and M.A. Koblinsky. 1984. Interventions for the control of the diarrhoeal diseases among young children: promotion of breast-feeding. Bull. WHO 62: 271-291.

(10) Grimmonprez, L. 1977. Les glucides du lait maternel. Med. Nutr. 13: 343-348.

(11) György, P., F. Robert, R.F. Norris, and C.S. Rose. 1954. Bifidus factor I. variant of Lactobacillus bifidus requiring a special growth factor. Arch. Biochem. Biophys. 48: 193-201.

(12) Holmgreen, J., A.M. Suennerholm, and M. Lindblad. 1981. Non immunoglobulin fraction of human milks inhibits bacterial adhesion (hemagglutination) and enterotoxin binding of $E$. coli and $V$. cholerae. Infect. Immun. 33: 136-141.

(13) Holmgreen, J., A.M. Svennerholm, and M. Lindblad. 1983. Receptor-like glycocompounds in human milk that inhibit classical and El Tor $V$. cholerae cell adherence (hemagglutination). Infect. Immun. 39: 143-154.

(14) Itoh, K., T. Mitsuoka, K. Sudo, and K. Suzuki. 1983. Comparison of fecal flora of mice based upon different strains and different housing conditions. Z. Versuchstierkd. 25: 135-146.

(15) Itoh, K., T. Oowada, and T. Mitsuoka. 1985. Characteristic faecal flora of NC mice. Lab. Anim. 19: 7-15.

(16) Johnson, J.L., C.F. Phelps, C.S. Cummins, J. London, and F. Gasser. 1980. Taxonomy of the Lactobacillus acidophilus group. Int. J. Syst. Bacteriol. 30: 53-68.

(17) Khun, R., and A. Gauhe. 1962. Isolierung einer nieder-molekularen, durch influenzavirus spaltabaren substanz aus milch. Chem. Ber. 95: 513-521.

(18) Kobata, A., K. Kamashita, and Y. Tachibana. 1978. Oligosaccharides from human milk. Methods Enzymol. 50: 216-220.

(19) Mantle, M., and A. Allen. 1978. A colorimetric assay for glycoproteins based on the periodic acid/Schiff stain. Biochem. Soc. Trans. 6: 607-609.

(20) Mitsuoka, T. 1984. Taxonomy and ecology of bifidobacteria. Bifidobacteria Microflora 3 : 11-28. 
(21) Neeser, J.R., A. Chambaz, M. Golliard, H. Link-Amster, V. Fryder, and E. Kolodziejcsyk. 1989. Adhesion of colonization factor antigen II-positive enterotoxigenic $E$. coli strains to human enterocytelike differentiated HT-29 cells: a basis for host-pathogen interactions in the gut. Infect. Immun. 57: 3727-3734.

(22) Polonvski, M., and A. Lespagnol. 1930. Un nouveau constituant glucidique du lait de femme, le gynolactose. C.R. Soc. Biol. 104: 553-555.

(23) Romond, C., H. Beerens, C. Neut, and J. Montreuil. 1980. Contribution à l'étude de la maternisation des laits: influence in vitro du lait maternel, du lait de vache et des laits maternisés sur la croissance de Bifidobacterium. Ann. Microbiol. (Inst. Pasteur) 131: 309-314.

(24) Romond, C., C. Neut, and H. Beerens. 1981. Etude comparative de deux moyens de transport destinés à maintenir en survie les anaérobies. Rev. Inst. Pasteur Lyon, 14: 133-139.

(25) Romond, M.B., C. Romond, H. Beerens, and P. Bourlioux. 1989. The "in vivo" effect of dietary buffering capacity on the bifidogenic activity of human milk oligosaccharides. M.E.H.D. 2: 29-36.

(26) Romond, M.B., M. Hamze, P. Bourlioux, and C. Romond. 1990. Etude des intéractions hôteBifidobacterium chez la souris axénique: caractérisation partielle des facteurs bifidigènes du contenu intestinal. Can. J. Microbiol. 36: 286-291.

(27) Stark, P.L., and A. Lee. 1982. The bacterial colonization of the large bowel of protein low birth weight neonates. J. Hyg. 15: 59-67.

(28) Viverge, D., L. Grimmonprez, G. Cassanas, L. Bardet, H. Bonnet, and M. Solere. 1985. Variations of lactose and oligosaccharides in milk from women of blood types secretor $\mathrm{A}$ or $\mathrm{H}$, secretor Lewis and secretor $\mathrm{H} /$ non secretor Lewis during the course of lactation. Ann. Nutr. Metab. 29: 13-17. 